\title{
Tell Me What You Eat and I Will Tell You Your Sociotype: Coping with Diabesity
}

\author{
Elliot M. Berry, M.D., F.R.C.P. ${ }^{1 *}$, and Sabina De Geest, Ph.D., R.N., F.A.A.N., \\ F.R.C.N. ${ }^{2}$ \\ ${ }^{\prime}$ Braun School of Public Health, Faculty of Medicine, Hebrew University of Jerusalem, Israel; and \\ ${ }^{2}$ Institute of Nursing Science, Faculty of Medicine, University of Basel, Switzerland
}

\begin{abstract}
The term sociotype has been introduced to describe the dynamic relationship of an individual with his/her social environment throughout life. The sociotype is a conceptual framework to highlight, in addition to biomedical pathways, the psycho-social and environmental factors necessary to understand responses to life stresses and patient self-management for chronic illness. The sociotype interacts with genotype expression through mate selection and metabolic programming, and with the phenotype to determine adaptation throughout life from birth to old age. Following on the work of Antonovsky, Engel, and McEwen, and others in the life and social sciences, the sociotype details and expands the many factors generally included in the environmental influences on a person's life identified here as the domains of health, relationships, and environment. Physiological mediators for sociotypic influences include: adrenal steroids and the sympathetic nervous system (allostatic load), and oxytocin (social neuroscience). The biological pathways are multiple through nutrition (essential dietary-derived amino- and fatty acids for neurotransmitter synthesis, caloric restriction, and diet-gene interactions), epigenesis, and metabolic programming. Nutrition influences growth and development, fertility and longevity, and also determines susceptibility to non-communicable diseases such as cardiovascular disease and cancer, and particularly diabetes and obesity, through in-utero effects, the development of intestinal flora (microbiome), and chronic stress. Thus the sociotype and nutrition are reciprocally related in both health and disease.
\end{abstract}

KEY WORDS: Coping, diabetes, environment, genotype, obesity, phenotype, relationships, sociotype

Citation: Berry EM, De Geest S. Tell Me What You Eat and I Will Tell You Your Sociotype: Coping with Diabesity. RMMJ 2012;3 (2):eo010. doi:10.5041/RMMJ.10077

Copyright: (C) 2012 Berry and De Geest. This is an open-access article. All its content, except where otherwise noted, is distributed under the terms of the Creative Commons Attribution License (http://creativecommons.org/licenses/by/3.0), which permits unrestricted use, distribution, and reproduction in any medium, provided the original work is properly cited.

Conflict of interest: No potential conflict of interest relevant to this article was reported.

Acknowledgment: We wish to thank Professor N.B. Grover for constructive criticism.

* To whom correspondence should be addressed. E-mail: elliotb@ekmd.huji.ac.il 
It is not the consciousness of men that determines their existence, but, on the contrary, it is their social existence that determines their consciousness. (Preface to the Critique of Political Economy, Karl Marx, 1859)

\section{INTRODUCING THE SOCIOTYPE}

The term sociotype has been introduced to describe the dynamic relationship of an individual with his/her social environment throughout the life trajectory. ${ }^{1}$ It is a framework for understanding how people manage life in general, and chronic disease in particular. The sociotype interacts with genotype expression through, for example, mate selection, epigenesis, and metabolic programming, and with the phenotype throughout life from birth to old age. The sociotype is an explanatory framework that analyses and expands the many factors usually included in the environmental influences on a person's life. The sociotype is constituted by individual health, relationships, and environment. Every person is thus a product of the prevailing mores and his/her "three-fold cord"-genotype, phenotype, and sociotype. Figure 1 shows these interactions.

\section{ORIGINS OF THE SOCIOTYPE}

The sociotype framework embraces many previous insights that have led to theoretical and derived concepts that position human functioning throughout life, health, and illness in a broader bio-psychosocial framework ${ }^{2}$ and describe how people cope with life circumstances.3,4 Therefore, the sociotype is a synthesis of the ideas of many scientists and health professionals from the disciplines of physiology, psychology, medicine, nursing, sociology, and anthropology. Major intellectual debts are acknowledged to the following thinkers and scientists who were interested in understanding the human situation. In alphabetical order they include: Adler, 5 Bandura, ${ }^{6}$ Berkman, ${ }^{7}$ Bowlby, ${ }^{8}$ Erikson, ${ }^{9}$ Frankl, ${ }^{10}$ Freud, ${ }^{11}$ Fromm, ${ }^{12}$ Greenfield, ${ }^{13}$ Harlow et al., ${ }^{14}$ Horney, ${ }^{15}$ Jung, ${ }^{16}$ Levi-Strauss, ${ }^{17}$ Lorenz, ${ }^{18}$ Marx, ${ }^{19}$ Maslow, ${ }^{20}$ Piaget, ${ }^{21}$ Rogers, ${ }^{22}$ Seligman, ${ }^{23}$ and Winnicott 24 . Even this list is not exhaustive but

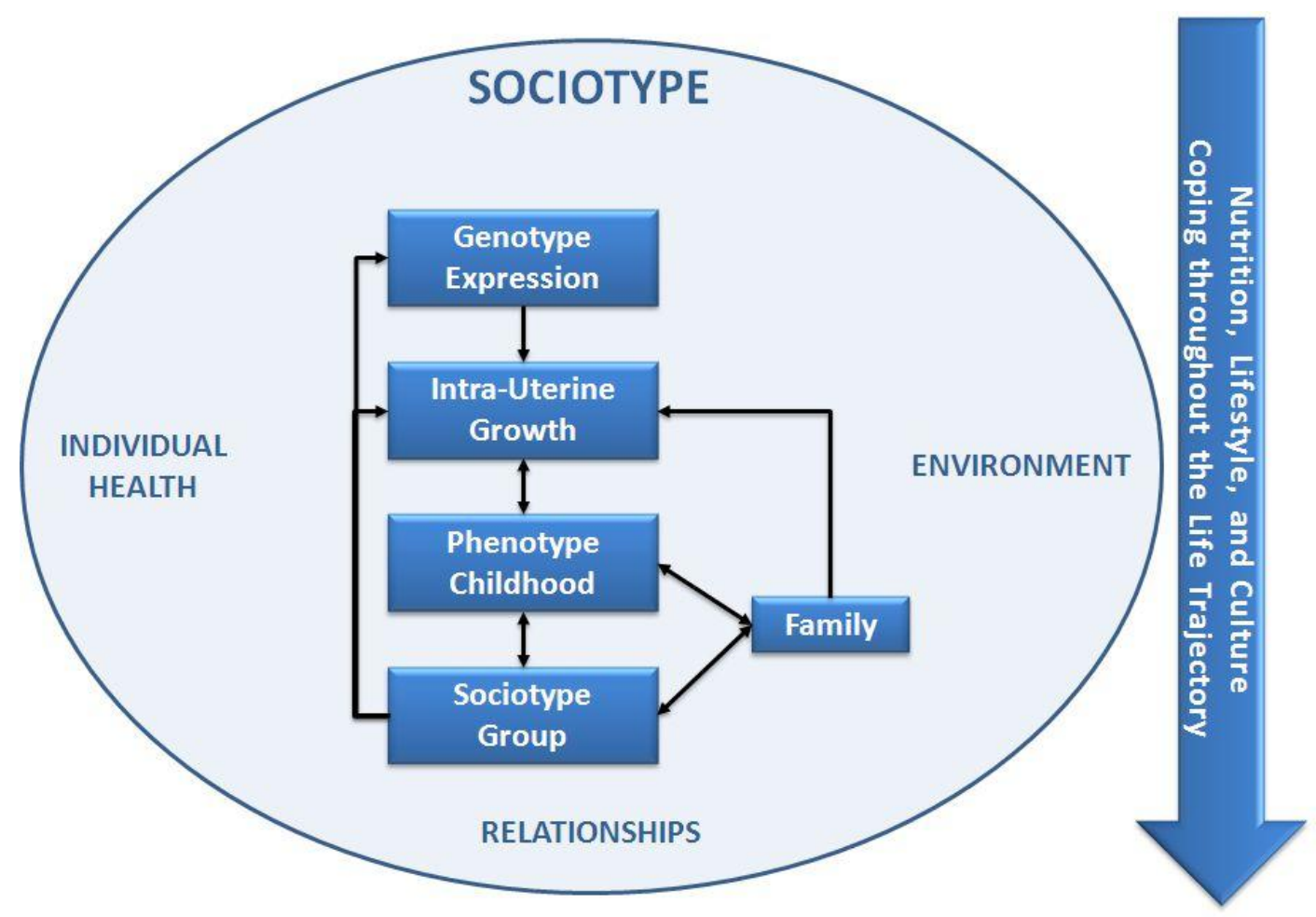

Figure 1. The relationship of the sociotype to genotypic expression and the phenotype throughout the life cycle. 
Table 1. The three domains of sociotypic inputs throughout the life trajectory.

Classification of some of the factors that are involved in dealing with different life situations. This Table should be read horizontally: some factors may operate and change at more than one life-time stage.

\begin{tabular}{|c|c|c|c|}
\hline Timeline & Individual Health & Relationships with... & Environment \\
\hline In utero & $\begin{array}{l}\text { Nutrition } \\
\text { Growth } \\
\text { Development }\end{array}$ & $\begin{array}{l}\text { Type of family (one or } \\
\text { two parents, same sex) }\end{array}$ & $\begin{array}{l}\text { Geographic demography } \\
\text { Urban or rural } \\
\text { Environmental exposure } \\
\text { Migration }\end{array}$ \\
\hline $\begin{array}{l}\text { Infancy and } \\
\text { Childhood }\end{array}$ & $\begin{array}{l}\text { Breast-feeding } \\
\text { Physical, psychological, and } \\
\text { emotional health } \\
\text { Special needs } \\
\text { Personality } \\
\text { Activity } \\
\text { Sleep pattern }\end{array}$ & $\begin{array}{l}\text { Parents (including their } \\
\text { relationship) } \\
\text { Siblings (birth order), } \\
\text { adoption, grandparents, } \\
\text { cousins, } \\
\text { Pets }\end{array}$ & $\begin{array}{l}\text { Education, stimulation } \\
\text { Indoctrination: Religious, } \\
\text { political } \\
\text { Realizing potential } \\
\text { Screen time (computer, TV) }\end{array}$ \\
\hline Adolescence & $\begin{array}{l}\text { Rites of passage } \\
\text { Health behaviors, including } \\
\text { sexuality } \\
\text { Substance use, including: } \\
\text { tobacco, alcohol, drugs, } \\
\text { eating behavior }\end{array}$ & $\begin{array}{l}\text { School friends, peer } \\
\text { group } \\
\text { Social networks }\end{array}$ & $\begin{array}{l}\text { Higher education } \\
\text { Vocational training } \\
\text { Military service }\end{array}$ \\
\hline Adulthood & $\begin{array}{l}\text { Personality type } \\
\text { Sense of humor } \\
\text { Creativity } \\
\text { Separation and individuation } \\
\text { Spiritual/religious-existential } \\
\text { belief system(s) } \\
\text { Self-knowledge } \\
\text { Shadows }\end{array}$ & $\begin{array}{l}\text { Spouse (mate selection) } \\
\text { and in-laws } \\
\text { Children (letting go) } \\
\text { At work: Superiors and } \\
\text { colleagues } \\
\text { Lovers } \\
\text { Sexual activity }\end{array}$ & $\begin{array}{l}\text { Employment, occupation, career } \\
\text { trajectory } \\
\text { Home, leisure time, music, art, } \\
\text { literature } \\
\text { Media and information } \\
\text { technology } \\
\text { Socio-economic class, religious } \\
\text { values }\end{array}$ \\
\hline Middle Age & $\begin{array}{l}\text { Coping strategies through life } \\
\text { events, including: Marriage, } \\
\text { birth, infertility, divorce, } \\
\text { menopause, retirement, } \\
\text { disease, bereavement, } \\
\text { misfortune, bankruptcy }\end{array}$ & $\begin{array}{l}\text { Care of parents } \\
\text { Grandchildren } \\
\text { Friends } \\
\text { Strangers, herd behavior }\end{array}$ & $\begin{array}{l}\text { Political system and ideology } \\
\text { National Identity } \\
\text { Social class, societal values, } \\
\text { social justice } \\
\text { Culture } \\
\text { Disasters: Natural, man-made }\end{array}$ \\
\hline Old Age & $\begin{array}{l}\text { Physiological, psychological, } \\
\text { and cognitive decline } \\
\text { Chronic disease } \\
\text { Chronic pain } \\
\text { Thoughts of mortality }\end{array}$ & $\begin{array}{l}\text { Family } \\
\text { Friends } \\
\text { Helpers }\end{array}$ & $\begin{array}{l}\text { Housing, sheltered living, } \\
\text { institution }\end{array}$ \\
\hline
\end{tabular}


indicates how long-standing were (and are) such attempts to formulate theories and coping that go beyond bio-medical factors. This approach may be summarized by the well-known saying of Sir William Osler (1849-1919): "It is more important to know what kind of patient has the disease than what kind of disease the patient has." From this developed the bio-psycho-social model of disease of Engel, which gave a static definition of the origins of disease rather than health and was less concerned with life-history dynamics. Antonovsky pioneered the concept of healthiness or salutogenesis, and positioned a person on a continuum between health and disease depending on the balance between risks and resources.3,25 He postulated the importance of a "sense of coherence" recognizing three areaspersonal, social, and ecological.

Following his scheme, in the sociotypic model these have been defined as the domains of individual health, relationships, and environment, respectively (Table 1). We define "successful" sociotypic development as a mature, healthy, independent individual functioning in, and contributing to, society according to his/her full potential. The sociotype is culture-dependent, and therefore there is no comprehensive definition of a "normal" sociotype.

The following are examples of some of the questions that the sociotype attempts to address in the three domains:

Health: How to live with special needs? How to cope with living following a stroke, with inflammatory bowel disease, rheumatoid arthritis, or posttransplant? How do Holocaust survivors survive?

Relationships: What determines how we choose our mates/partners? How to deal with divorce or bereavement?

Environment: How to deal with bankruptcy, job dismissal, retirement? How to deal with wars and their aftermath?

Some of the above overlap domains in their effects-consider the consequences of a serious road traffic accident. The answers are not given only by quantitative methodologies but require a combination of qualitative and quantitative methodologies (mixed methods).

The thrust of this paper is to explain the sociotype framework in more detail to understand the multiple interrelations of its components necessary for functioning in health and illness. We will first describe the different aspects of the three domains and then indicate the crucial importance of nutrition on sociotypic development from pregnancy to old age in health and in relation to the development of diabesity.

\section{CONCEPTUALIZING THE SOCIOTYPE: THE THREE DOMAINS-INDIVIDUAL HEALTH, RELATIONSHIPS AND ENVIRONMENT}

Table 1 is an attempt to arrange the sociotypic factors acting at different times during the life cycle as inputs in the three domains. It is not exhaustive and varies with the individual's location and living conditions. The entries vary widely as to importance or influence in any given individual, although some attempt has been made to give a hierarchical structure.

In the health domain there is the importance of accrued life experiences, beginning with bonding and imprinting, influencing personality development and even a sense of humor. These develop slowly in human maturation as the period of infancy, childhood dependency, and adolescence has increased during hominid evolution, as well described by Hochberg ${ }^{26}$ and Konner. ${ }^{27}$ Secure or insecure infantile and childhood parental attachment is considered to program reproductive strategies. ${ }^{28}$ Sleeping, sexuality, and eating (the dark side of the moon) occupy a third of a person's life and are most relevant to his/her equilibrium, yet are rarely discussed in most clinical case descriptions.

The domain of relationships considers those of family, peer group and friends, lovers, and people in authority. Mate selection is a key example of the reciprocal interaction between the phenotype and the sociotype, determining the genetic make-up of the next generation by shuffling the gene pool-but it is yet to be determined how much is biologically or psychologically driven. ${ }^{29,30}$ It is suggested that humans select major histocompatibility complex (MHC)-dissimilar partners through olfactory (pheromone) and other cues so as to enhance offspring heterozygosity; the effect of perfumes, cosmetics, and deodorants on this is a major concern. ${ }^{31}$ Such biological mechanisms are examples of the effect of the phenotype on the sociotype. Marriage avoidance among their peer group by kibbutz children is clearly due to sociotypic influences. ${ }^{32}$ Dealing with parental approval can be a lifelong task. Communication is at a number of 
levels-intellectual, emotional, spiritual, and physical.

Factors covered by the environment domain include education, employment, economic circumstances, and time spent at work, home, and during leisure activities. Political, ideological, and societal values influence behavior. Most people appear to be Marxist within the family, yet Capitalist outside of it.33 The effects of disasters, whether natural (tsunamis, earthquakes) or man-made (wars, economic crises), have long-term effects on the sociotype. The recent economic crisis in Greece has already had health consequences. 34,35 Other factors that have a significant influence on health behaviors are social networks, media, and the information technology revolution. ${ }^{6}$ Religiosity spans all domains in attempting to provide a meaning to one's situation as well as communal support, 37 while others find in humanism an alternative answer to such needs. There may be counter-pressures relating to individuality and creativity.

The position of elements in Table 1 is open to debate. For instance, societal values found under environment could also be placed in health or relationships, which only shows that these factors are not easily categorized. Yet this is not a problem; rather, the three domains may be likened to the palate of the three primary colors that shade the many different influences of, and responses to, the sociotype as has been shown for the sense of coherence scale. ${ }^{8}$ Thus, there may be intermediate groupings and cross-classifications among the domains. For example, health-relationships include maternal bonding and attachment, community and family support systems. Environment-relationships express socio-economic conditions and work opportunities. National identity factors are examples of cross-boundary issues as between French and Flemish speakers (in Belgium), Rumanians and Moldovans, Israeli and Palestinian Arabs, North and South Irish, and elsewhere. The healthenvironment axis would include the physical environment and air pollution as well as access to health systems and treatment. Catastrophes such as a war or the global economic situation affect all three domains.

Sociotypic factors work at more than one stage in life (e.g. physical handicap, existential doubts, or a chronic disease). For example, natural or man-made disasters and disease may occur at any time; spiritual or ideological beliefs and taste in music may also change with age and maturity. It is thus obvious that the various influences on the sociotype may operate and change at different times and to different extents throughout the life cycle. Education is not just from childhood to university but has farreaching effects throughout life. In different societies other factors may be relevant such as cultural acceptance of disease, health literacy, and the impact of social networks. And overall, there is the influence of chance and the realization that life events cannot be easily predicted or classified. There may even be a danger that the sociotype encompasses so many variables that, in the words of the Talmudic dictum, "If you grasp a lot you cannot hold it, if you grasp a little you can hold it" (Babylonian Talmud tractate Rosh Hashana 4b). Thus, the challenge is to find the specific factors operating for any given person in the particular life situation.

\section{BIOLOGICAL PATHWAYS FOR SOCIOTYPIC INFLUENCE}

The idea of the sociotype would be of little value if there were no biological pathways through which it could influence health and functioning. It provides a bridge between individual health and public health.7,39 The concepts of allostasis and allostatic load have been championed by McEwen to describe how chronic stress-"wear and tear"-can affect well-being through over-action of adrenal steroid secretion and the sympathetic nervous system.4,40 Oxytocin and vasopressin secretion are other pathways with multiple effects on birth, lactation, bonding, mate selection, and aggression. There are gender differences in the sociotypic responses, with females tending to (de)fend and befriend and males to fight or flight. ${ }^{41}$ This has become the basis for the new discipline of social neuroscience. We believe, however, that one of the major pathways of influence on sociotypic development during the human life cycle is through nutrition, and this is shown in Figure 2.

\section{THE ROLE OF NUTRITION ON THE SOCIOTYPE DURING THE LIFE CYCLE}

Nutrition may be likened to the fuel that drives the body's physical and psychological motor and should therefore be of the highest octane. From the research on the neonatal origins of adult disease (Barker hypothesis and metabolic programming) 42 and longevity (telomere lengths $43-45$ ) it is now recognized that nutritional influences begin at 


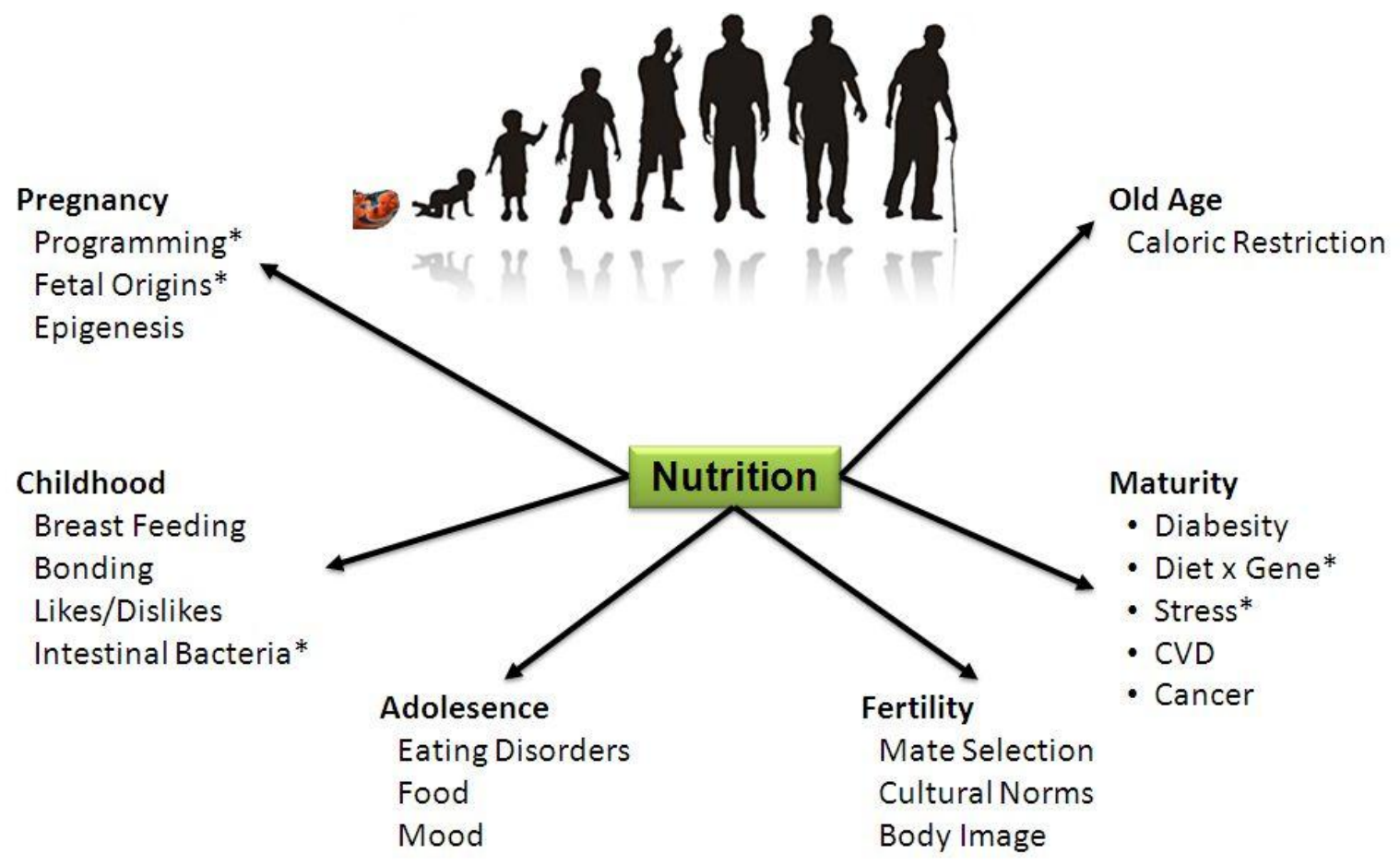

Figure 2. The effects of nutrition on the sociotype during the life cycle. *Factors involved in the pathogenesis of diabesity as discussed in the text.

minus nine months. Famine pregnancy studies from Holland 46 and China 47 confirm the increase in schizophrenia in the adult progeny. Nutrition affects many stages: pregnancy, breast-feeding, and weaning. The concept of the bonding and the "good and bad breast" stresses the importance of parenting attitudes. Milk contains endocannabinoids which are crucial for infant suckling. ${ }^{48}$ The endocannabinoid neurotransmitter modulator system is derived from essential omega-6 polyunsaturated fatty acids necessary for the synthesis of 2 arachidonyl glycerol and regulates appetite in a quasi-feedback loop.49 In rodents, maternal grooming influences serotonin activity, steroid secretion, and the methylation and acetylation status of gene expression..$^{\circ}$

Adolescents are vulnerable to cultural influences concerning body image and to the development of eating disorders. In some people nutrition may affect their cognitive assessments (food and mood). ${ }^{51}$ Three of the principal neurotransmittersserotonin, norepinephrine, and dopamine-are derived from essential amino-acids tryptophan, phenylalanine, and tyrosine. It is possible that some of the abnormal cognitive functioning in anorexia is due a lack of such precursors, which can be alleviated by oral tyrosine supplementation (Israel, Avraham \& Berry, unpublished data). Eating disorders are examples par excellence of culture-bound diseases of the sociotype ("nothing tastes as good as thinness feels"), as discussed elsewhere. ${ }^{1}$ Brain peptides-orexins-provide a link between eating behavior, body weight, and sleep. ${ }^{22,53}$

Fertility: The age of the menarche is dependent on the amount of energy stores (adipose tissue) required to sustain a pregnancy 54 and has become earlier in most countries55 as nutrition has improved; conversely, amenorrhea is a (necessary) consequence of anorexia.

Maturity: Discussion of the many examples of diet-gene interactions ${ }^{5} 6$ is beyond the scope of this review but has obvious relevance to the sociotype. It has been said that a family who eats together, sticks together.

Old age: Caloric restriction is the one proven means to increase longevity and involves inter alia sirtuin pathways. 57 Leptin, which is secreted in proportion to adipose mass, has multiple functions. We have shown it to be involved in survival under 
conditions of severe caloric deprivation $5^{8}$ as well as being neuro-protective.59 Indeed, recent studies suggest that survival of severely ill intensive care patients is associated with higher levels of leptin (Sviri, Avraham, Berry, et al., submitted). Of interest is that omega-3 essential dietary fatty acids may exhibit some actions similar to those of leptin regarding survival and cognitive function. ${ }^{60}$

Finally, nutrition is also involved in resistance to infectious diseases through effects on the immune system and intestinal bacteria. ${ }^{61}$ The sociotype influences involve public health measures concerning sanitation and immunization policies.

\section{THE PROBLEM OF DIABESITY}

The role of nutrition in the pathogenesis of noncommunicable diseases such as diabesity, cardiovascular disease, and cancer are well known. ${ }^{62}$ There are at least three pathways whereby nutritional status can lead to the development of diabesity: (1) impaired fetal growth, (2) intestinal bacteria, and (3) increased allostatic load of chronic stress (Figure 2). $4^{\circ}$ If a pregnant woman is stressed or malnourished, the fetus' development may be affected, leading to increased risk of insulin dependent diabetes mellitus (NIDDM), cardiovascular disease, and hypertension in later life..$^{2}$ Intestinal flora can regulate insulin sensitivity through a number of pathways involving fatty acid oxidation, inflammatory lipopolysaccharides (LPS), short chain fatty acid lipogenesis, incretin secretion, and butyrate production. ${ }^{61}$ It remains to be determined how diet regulates the colonization of intestinal bacteria (the microbiome) and how they may, in turn, influence energy balance. ${ }^{63}$ Finally, metabolic efficiency increases with age, leading to the relentless weight increase observed in developing countries over the decades of life.

The sociotypic effects of the environment are clearly demonstrated by comparing the normal to mild overweight of Pima Indians living traditionally in Mexico to the severe obesity among their fellow tribe members and relatives living affluently in Arizona on reservations, some running casinos. ${ }^{64}$ Thus the pandemic of obesity may be considered a normal response to an abnormal environment that encourages too much eating and too little activity. In industrialized countries obesity is inversely related to socio-economic status and years of education. That the opposite occurs in low-income countries shows the influence of socio-economic and cultural norms. ${ }^{65}$ Of course there is a genetic component to obesity and metabolic efficiency, which was an advantage during evolution when food sources were inconstant. ${ }^{66}$ However, in recent times this has turned into a handicap. Obesity, therefore, is inherited but not inevitable, and cannot occur unless there is a permissive "obesogenic" environment. ${ }^{67}$

The effects of social networks on the sociotype have been described for obesity, ${ }^{68}$ and recent research has shown the benefits of moving house on the prevalence of diabetes and obesity. ${ }^{69}$ This would not seem to be a universally available option, and the mechanisms are not clear, though presumably they involve changes in life-style influenced by the new neighborhood.

\section{THE SOCIOTYPE OF DIABESITY AND CHRONIC ILLNESS: PATIENT SELF- MANAGEMENT}

Table 2 lists aspects of the sociotype in the three domains-in addition to the factors detailed in Table 1-that are required for coping with chronic disease, using diabesity as an example. The sociotypic map will change during the course of an illness. For instance, the response to a relapse following cancer therapy or in multiple sclerosis will not be the same as that at the initial diagnosis. And in a diabetic patient, the need for dialysis or an amputation will produce a different sociotypic response than that for commencing injections of insulin.

The key factors integral to the management of diabesity are a change in diet and life-style, ${ }^{70}$ and encouraging self-management, ${ }^{71,72}$ using a combination of techniques of which motivational interviewing by health professionals is one example.73 Further, investments need to be made in strengthening competencies of the health team and implementation of new care models for a multidimensional approach to patient management. This involves new relationships with the case manager, hospital specialists, and carers.

Self-management also means that patients have the confidence to follow their prescribed therapy, to avoid health deterioration, and to preserve function. 74,75 It is hypothesized that the sociotype is essential for the ability to succeed in the three selfmanagement tasks of: (1) medical management, (2) role management, and (3) emotional management. For diabetes patients, the first task involves the skills needed in leading a healthy life-style and 
Table 2. Additional factors in the three domains of the sociotype that relate specifically to chronic disease management as in diabesity.

\begin{tabular}{|l|l|l|}
\hline \multicolumn{1}{|c|}{ Individual Health } & \multicolumn{1}{|c|}{ Relationships } & \multicolumn{1}{|c|}{ Environment } \\
\hline $\begin{array}{l}\text { Macro-level: Health care system, health } \\
\text { benefits }\end{array}$ & Significant other and family & $\begin{array}{l}\text { Access to health centers, } \\
\text { mobility }\end{array}$ \\
\hline $\begin{array}{l}\text { Meso-level: Health insurance, relations } \\
\text { with health maintenance organization } \\
\text { (HMO), pharmacists }\end{array}$ & $\begin{array}{l}\text { Community primary care } \\
\text { case manager and medical } \\
\text { team }\end{array}$ & $\begin{array}{l}\text { Facilities for chronic care: } \\
\text { clinics, dialysis centers, day- } \\
\text { care }\end{array}$ \\
\hline $\begin{array}{l}\text { Micro-level: Patient care process, health } \\
\text { literacy, treatment, and side-effects: } \\
\text { adapting, adjusting to a new reality }\end{array}$ & $\begin{array}{l}\text { Case manager } \\
\text { Hospital specialist } \\
\text { Medical team and health } \\
\text { professionals }\end{array}$ & Financial circumstances \\
\hline $\begin{array}{l}\text { Physical status, nutrition, activity, self- } \\
\text { management }\end{array}$ & $\begin{array}{l}\text { Continuity and coordination } \\
\text { of care }\end{array}$ & $\begin{array}{l}\text { Housing facilities (daily living) } \\
\text { Access to care, personal } \\
\text { hygiene facilities, etc. }\end{array}$ \\
\hline $\begin{array}{l}\text { Mental health, personality type, health } \\
\text { beliefs, taking responsibility for treatment } \\
\text { options }\end{array}$ & $\begin{array}{l}\text { Patient self-management } \\
\text { support groups }\end{array}$ & Ability to continue working \\
\hline $\begin{array}{l}\text { Coping and compliance strategies, denial } \\
\text { Dependency, loss of control } \\
\text { Complications and side-effects } \\
\text { Eyesight } \\
\text { Peripheral vascular disease (amputations) } \\
\text { Kidneys (dialysis) } \\
\text { Impotence }\end{array}$ & Friends & $\begin{array}{l}\text { Cultural acceptability of } \\
\text { illness }\end{array}$ \\
\hline $\begin{array}{l}\text { Health literacy } \\
\text { Alternative medicine }\end{array}$ & Carers & Information technology \\
\hline
\end{tabular}

following correctly the medication regimen. In addition, the patient has to deal with the possible side-effects of the treatment as well as disease progression (macro- and micro-angiopathy). Role management refers to the managing of relationships that change or come under pressure during the course of the chronic illness. The third task of emotional management refers to the skills patients need to cope with emotional states or challenges associated with their illness. 74

Self-management support consists of a portfolio of techniques and tools required to achieve these tasks, which calls for a fundamental transformation of the patient-caregiver relationship into a collaborative partnership. 75 One practical way is to draw on the experience of patients from similar backgrounds who are already successful in managing their disease using, for example, the methodologies of positive deviance. 76,77
The impact of the disease on the family cannot be overestimated in coping with new roles, and there may be the problem of impotence affecting sexuality. Obviously there are financial issues, especially if the patient is poorly insured and unable to continue his/her work.

Evidence from chronically ill populations, including diabetes, shows that improved outcomes occur when care systems shift from acute to chronic care paradigms, particularly if they include support

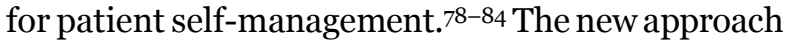
requires moving from predominantly acute-caredriven management plans which generally ignore behavioral, psycho-social, and environmental factors, towards models that guarantee effective long-term illness care. These should combine the following features: (1) provide comprehensive, multidisciplinary care, (2) integrate and co-ordinate care along the care continuum, (3) be disease or 
population-specific, (4) include tools to promote patient self-management, (5) be evidence-based, and (6) imbed information technology. $78,80,85,86$

There is also good evidence that adherence improves diabetic control 87 thereby delaying complications. ${ }^{88,89}$ The challenge for health teams lies in promoting this goal, the economic consequences of which are obvious. ${ }^{90,91}$ Given that clinical results depend principally on patients' daily self-management, tackling non-medical risk factors through interventions to support it sociotypically represents a potentially powerful pathway to improve long-term outcomes in the chronically ill.

\section{MANAGING THE PATIENT WITH CHRONIC DISEASE}

For any given patient, the ability to cope with chronic disease is dependent on elements in the three sociotypic domains which, in turn and to varying degrees, determine the long-term outcome. The lists of factors in Tables 1 and 2 suggest that conventional medical education does not yet prepare future practitioners for such a task. It is difficult to envisage all the skills required since they are multidisciplinary, involving, in addition to medicine, the integration of the sciences of sociology, psychology, and anthropology inter alia. Systems biology has been proposed as the new direction, but the initial versions of it are still too bio-reductionist to encompass the necessary sociotypic elements. ${ }^{1,92,93}$

In order to assess patients with chronic diseases, the medical history has to be expanded to include consideration of the sociotype. This is much more than the conventional social history of living conditions and socio-economic circumstances. Furthermore, mental and physical health interact such that coping strategies may have "trade-offs" between them. A recent study indicates that they must be considered jointly when researching the causes of disparities across racial groups and questions implicit assumptions concerning associations between social disadvantages, health behaviors and mental health. ${ }^{94}$ A sociotypic history is an attempt to understand the totality of developmental experience-“to step into the patient's shoes"-that determines reactions, responses, and obstacles to self-management.

\section{FOR THE FUTURE}

It is clear that many of the factors detailed in Tables 1 and 2 do not lend themselves readily to quantification, especially with regard to relationships, and it may not be possible to give a global sociotype score. The point is that for any given patient there will be relevant issues that have to be assessed separately in each of the three domains. Future projects will identify both biomarkers $4^{\circ}$ and questionnaires that are relevant to the challenge of typing the sociotype (as examples: for family function, family Apgar score, 95 stress, ${ }^{96,97}$ quality of life, ${ }^{98}$ and social adaptability 99 ). This means that in its strong form sociotypic analysis will require establishing rigorous methods to investigate and quantify its effects.40,75 In its weak form sociotypic analysis is a way to highlight those psycho-social and environmental factors relevant to health and illness. Both approaches should prove to be a robust way of broadening health professionals' vision of realities in health care, which will then enable appropriate individual, community, or national interventions for disease prevention and chronic disease management. Such knowledge could then inform policy and practice to improve public health. The expectation is that the greater the consideration of the sociotype, the better will be the treatment outcome and the patient's self-management. To test this hypothesis is the future challenge. The comprehensiveness of the sociotype requires that its analysis be approached in a graded manner; the role of nutrition in its development throughout life would seem to be a suitable first step.

\section{CONCLUSIONS}

This paper has indicated how nutrition in its widest sense has a major influence on the development of the sociotype throughout the life cycle. This was anticipated at the individual level by Brillat-Savarin (1755-1826) in his well-known saying: "Tell me what you eat, and I will tell you what you are." We may broaden this construct to the level of relationships: "Tell me how a family eats, and I will tell you how it functions." And finally, the extension of sociotypic analysis and nutrition to the level of the environment: "Tell me how a nation eats, and I will tell you its values"-do, for example, children go to bed hungry? (Food security). The sociotype determines how an individual adjusts to life in 
general and disease in particular. Thus, there is justification in claiming "Tell me your sociotype, and I will tell you what you eat" (and vice versa), from which then follows "Tell me your sociotype, and I will tell you how you cope."

One cannot do better for a conclusion than quote the words of Spinoza (1632-1677) in Tractatus Theologico-Politicus, bk. 1, pt. 4:

Sedulo curavi, humanas actiones non ridere, non lugare, neque detestari, sed intelligere. I have striven not to laugh at human actions, not to weep at them, nor to hate them, but to understand them.

Indeed, it is not our role to be judgmental, but rather to try to understand better the person (patient) to help him/her cope with the disease and develop the full potential of his/her unique sociotype.

\section{REFERENCES}

1. Berry EM. The role of the sociotype in managing chronic disease: integrating bio-psycho-sociology with systems biology. Med Hypotheses 2011;77:6103. Full Text

2. Engel GL. The need for a new medical model: a challenge for biomedicine. Science 1977;496:129-36. Full Text

3. Antonovsky A. Health, Stress and Coping. San Francisco: Josey-Bass; 1979.

4. McEwen BS. Protective and damaging effects of stress mediators. N Engl J Med 1998;338:171-9. Full Text

5. Adler A. Understanding Human Nature. New York: Greenberg; 1927.

6. Bandura A. Social Foundations of Thought and Action: A Social Cognitive Theory. Englewood Cliffs, NJ: Prentice-Hall; 1986.

7. Berkman LF, Glass T, Brissette I, Seeman TE. From social integration to health: Durkheim in the new millennium. Soc Sci Med 2000;51:843-57. Full Text

8. Bowlby J. The Making and Breaking of Affectional Bonds. London: Routledge; 1989.

9. Erikson EH. Eight ages of man. Int J Psychiatry 1966;2:281-97.

10. Frankl V. Man's Search for Meaning. An Introduction to Logotherapy. London: Random House/Rider; 2004.
11. Freud S. Civilisation and Its Discontents. New York: Dover Publications; 1994.

12. Fromm E. Beyond the chains of illusion: my encounter with Marx and Freud. New York: Simon and Schuster; 1962.

13. Greenfield PM. Linking Social Change and Developmental Change: Shifting Pathways of Human Development. Dev Psychol 2009;45:401-18. Full Text

14. Harlow HF, Harlow MK, Suomi SJ. From thought to therapy: lessons from a primate laboratory. Am Sci 1971;59:538-49.

15. Horney K. Neurosis and Human Growth. New York: Norton; 1950.

16. Jung CG. Man and His Symbols. London: Aldus Books; 1964.

17. Lévi-Strauss C. Structural anthropology. London, Great Britain: Allen Lane / Penguin Press; 1968.

18. Lorenz K. Behind the Mirror. New York: Harcourt Brace Jovanovich; 1977.

19. Geras N. Marx and Human Nature: Refutation of a Legend. London: Schocken Books; 1983.

20. Maslow AH. A theory of human motivation. Psychol Rev 1943;50:370-96. Full Text

21. Piaget J. Behavior and Evolution. New York: Pantheon Books; 1978.

22. Rogers C. A Way of Being. Boston: Houghton Mifflin; 1980.

23. Seligman MEP. What You Can Change and What You Can't: The Complete Guide to Successful SelfImprovement. New York: Knopf; 1993.

24. Winnicott DW. The Family and Individual Development. London: Tavistock; 1965.

25. Antonovsky A. The structure and properties of the sense of coherence scale. Soc Sci Med 1993;36:72533. Full Text

26. Hochberg Z. Evolutionary perspective in child growth. RMMJ 2011;2:1-13. Full Text

27. Konner M. The Evolution of Childhood. London: Belknap Press; 2010.

28. Del Giudice M. Sex, attachment, and the development of reproductive strategies. Behav Brain Sci 2009;32: 1-67. Full Text

29. Zahavi A. Mate selection-a selection for a handicap. J Theor Biol 1975;53:205-14. Full Text

30. Buss DM, Barnes M. Preferences in human mate selection. J Pers Soc Psychol 1986;50:559-70. Full $\underline{\text { Text }}$ 
31. Havlicek J, Roberts SC. MHC-correlated mate choice in humans: A review. Psychoneuroendocrinology 2009;34:497-512. Full Text

32. Shepher J. Mate Selection Among Second Generation Kibbutz Adolescents and Adults: Incest Avoidance and Negative Imprinting. Arch Sex Behav 1971;1:293-307. Full Text

33. Kolakowski L. My Correct Views on Everything. South Bend, IN: St Augustine's Press; 2004.

34. Kentikelenis A, Karanikolos M, Papanicolas I, Basu S, McKee M, Stuckler D. Health effects of financial crisis: omens of a Greek tragedy. Lancet 2011;378:1457-8. Full Text

35. Economou M, Madianos M, Theleritis C, Peppou LE, Stefanis CN. Increased suicidality amid economic crisis in Greece. Lancet 2011;9801:1459. Full Text

36. Schubart JR, Stuckley HL, Ganeshamoothy A, Sciamanna CN. Chronic Health conditions and internet behavioral interventions: a review of factors to enhance user engagement. Comput Inform Nurs 2001;29:81-92. Full Text

37. Putnam RD. Bowling Alone: The Collapse and Revival of American Community. New York: Simon \& Schuster; 2000.

38. Schnyder U, Büchi S, Sensky T, Klaghofer R. Antonovsky's Sense of Coherence: Trait or State? Psychother Psychosom 2000;69:296-302. Full Text

39. IOM (Institute of Medicine). 2012 Living well with chronic illness: a call for public health action. Washington, DC: The National Academic Press. .

40. Juster RP, McEwen BS, Lupien SJ. Allostatic load biomarkers of chronic stress and impact on health and cognition. Neurosci Biobehav Rev 2010;35:2-16. Full Text

41. Insel TR. The challenge of translation in social neuroscience: A review of oxytocin, vasopressin, and affiliative behavior. Neuron 2010;65:768-79. Full $\underline{\text { Text }}$

42. Barker DJP. The developmental origins of adult disease. J Am Coll Nutr 2004;23:588-95.

43. Epel ES, Blackburn EH, Lin J, et al. Accelerated telomere shortening in response to life stress. Proc Natl Acad Sci U S A 2004;101(49):17312-5. Full Text

44. Entringer S, Epel ES, Kumstac R, et al. Stress exposure in intrauterine life is associated with shorter telomere length in young adulthood. Proc Natl Acad Sci U S A 2011;108:E513-8. Full Text

45. Heidinger BJ, Blount JD, Bonera W, Griffiths K, Metcalf NB, Monaghana P. Telomere length in early life predicts lifespan. Proc Natl Acad Sci U S A 2012;109(5):1743-8. Full Text
46. Brown AS, van Os J, Driessens C, Hoek HW, Susser ES. Further evidence of relation between prenatal famine and major affective disorder. Am J Psychiatry 2000;157:190-5. Full Text

47. St Clair D, Xu M, Wang P, et al. Rates of Adult schizophrenia following prenatal exposure to the Chinese famine of 1959-1961. JAMA 2005;204:55762. Full Text

48. Mechoulam R, Berry EM, Avraham Y, Di Marzo V, Fride E. Endocannabinoids, feeding and sucklingfrom our perspective. Int J Obes 2006;30:S24-S8. Full Text

49. Berry EM, Mechoulam R. Effects of cannabinoids in feeding and appetite. Pharmacol Ther 2002;95:18590. Full Text

50. Szyf M. DNA methylation, the early-life social environment and behavioral disorders. J Neurodevelop Disord 2011;3:238-49. Full Text

51. Canetti L, Bachar E, Berry EM. Food and Emotion. Behav Processes 2002;60:157-64. Full Text

52. Martins PJF, Marques MS, Tufik S, D'Almeida V. Orexin activation precedes increased NPY expression, hyperphagia, and metabolic changes in response to sleep deprivation. Am J Physiol Endocrinol Metab 2010;298:E726-34. Full Text

53. Vianna CR, Coppari R. A treasure trove of hypothalamic neurocircuitries governing body weight homeostasis. Endocrinology 2011;152:11-18.

54. Frisch RE, McArthur JW. Menstrual cycles: fatness as a determinant of minimum weight for height necessary for their maintenance or onset. Science 1974;185:949-51. Full Text

55. Wyshak G, Frisch RE. Evidence for a secular trend in age of menarche. N Engl J Med 1982;306:1033-5. Full Text

56. Kalupahana NS, Moustaid-Moussa N. Overview of symposium "Systems Genetics in Nutrition and Obesity Research". J Nutr 2011;141:512-14. Full Text

57. Guarente L. Epstein Lecture: Sirtuins, aging, and medicine. N Engl J Med 2011;364:2235-44. Full Text

58. Dagon Y, Avraham Y, Magen Y, Gertler A, Ben-Hur T, Berry EM. Nutritional status, cognitive function and survival-a new role for leptin and AMPK. J Biol Chem 2005;280:42142-48. Full Text

59. Avraham Y, Davidi N, Porat M, et al. Leptin reduces infarct size in association with enhanced expression of CB2, TRPV1, SIRT-1 and leptin receptors. Cur Neurosci Res 2010;7:136-43. Full Text

6o. Avraham Y, Saidan M, Mevorach R, et al. Fish oil promotes survival and protects against cognitive decline in severely undernourished mice by normal- 
izing satiety signals. $\mathrm{J}$ Nutritional Biochem 2011;22:766-76. Full Text

61. Tilg H, Kaser A. Gut microbiome, obesity, and metabolic dysfunction. J Clin Invest 2011;121:212632. Full Text

62. Global Strategy on Diet, Physical Activity and Health. A Framework to Monitor and Evaluate Implementation. Geneva: World Health Organization; 2006.

63. Turnbaugh PJ, Ley RE, Mahowald MA, Magrini V, Mardis ER, Gordon JI. An obesity-associated gut microbiome with increased capacity for energy harvest. Nature 2006;444:1027-31. Full Text

64. Ravussin E, Valencia ME, Esparza J, Bennett PH, Schulz LO. Effects of a traditional lifestyle on obesity in Pima Indians. Diabetes Care 1994;17:1067-74. Full $\underline{\text { Text }}$

65. Zimmet P, Alberti KG, Shaw J. Global and societal implications of the diabetes epidemic. Nature 2001;414:782-7. Full Text

66. Neel JV. Diabetes mellitus: a "thrifty" genotype rendered detrimental by "progress"? Am J Hum Genet 1962;14:353-62.

67. Walley AJ, Asher JE, Froguel P. The genetic contribution to non-syndromic human obesity. Nat Rev Genet 2009;10:431-42. Full Text

68. Christakis NA, Fowler JH. The spread of obesity in a large social network over 32 years. N Engl J Med 2007;387:370-9. Full Text

69. Ludwig J, Sanbonmatsu L, Gennetian L, et al. Neighborhoods, obesity, and diabetes-a randomized social experiment. N Engl J Med 2011;365:1509-19. Full Text

70. Tuomilehto J, Lindström J, Eriksson JG, et al. Prevention of type 2 diabetes mellitus by changes in lifestyle among subjects with impaired glucose tolerance. N Engl J Med 2001;344:1343-50. Full Text

71. Funnell MM, Anderson RM. Empowerment and selfmanagement of diabetes. Clin Diabetes 2004;22:1237. Full Text

72. King DK, Glasgow RE, Toobert DJ, et al. Self-efficacy, problem solving, and social-environmental support are associated with diabetes self-management behaviors. Diabetes Care 2010;33:751-3. Full Text

73. Chen SM, Creedy D, Lin HS, Wollin J. Effects of motivational interviewing intervention on self management, psychological and glycemic outcomes in type 2 diabetes: A randomized controlled trial. Int J Nurs Stud 2011 Dec 30 [Epub ahead of print]. Full $\underline{\text { Text }}$
74. Lorig KR, Holman H. Self-management education: history, definition, outcomes, and mechanisms. Ann Behav Med 2003;1:1-7. Full Text

75. de Silva D. Evidence: Helping People Help Themselves. London: The Evidence Centre; 2011.

76. Marsh DR, Schroeder DG, Dearden KA, Sternin J, Sternin M. The power of positive deviance. BMJ 2004;329:1177-9. Full Text

77. Berry EM, De Geest S. Diabesity and positive deviance: the challenge of adherence to long-term therapies. In: Rosen B, Israeli A, Shortell B, eds. Improving Health and Healthcare; Tel Hashomer: Israel National Institute for Health Policy and Health Services Research; 2011:420-31.

78. Yach D. Innovative Care for Chronic ConditionsBuilding Blocks for Action. Geneva: World Health Organization; 2002.

79. Epping-Jordan JE, Pruitt SD, Bengoa R, Wagner EH. Improving the quality of health care for chronic conditions. Qual Saf Health Care 2004;13:299-305. Full Text

80. Wagner EH, Bennett SM, Austin BT, Greene SM, Schaefer JK, Vonkorff M. Finding common ground: patient-centeredness and evidence-based chronic illness care. J Altern Complement Med 2005;11 (Suppl 1):S7-15. Full Text

81. Nolte E, McKee M, eds. Caring for People with Chronic Conditions. A Health Care Systems Perspective. Open University Press, Maindenhead, McGraw Hill; 2008.

82. Evans T, Van Lerberghe W, Rasanathan K, Mechbal A, eds. The World Health Report 2008. Primary Health Care-Now More Than Ever. Geneva: World Health Organization; 2008.

83. Coleman K, Austin BT, Brach C, Wagner EH. Evidence on the chronic care model in the new millennium. Health Aff (Millwood) 2009;28:75-85. Full Text

84. Busse R, Blumer M, Scheller-Kreinsen D, Zetner A, eds. Tackling Chronic Diseases in Europe. Strategies, Interventions and Challenges. United Kingdom: European Observatory on Health Systems and Policies, World Health Organization; 2010.

85. Bodenheimer T, Lorig K, Holman H, Grumbach K. Patient self-management of chronic disease in primary care. JAMA 2002;288:2469-75. Full Text

86. Bodenheimer T, Wagner E, Grumbach K. Improving primary care for patients with chronic illness: the chronic care model, Part 2. JAMA 2002;288:190914. Full Text 
87. Kim N, Agostini JV, Justice AC. Refill adherence to oral hypoglycemic agents and glycemic control in veterans. Ann Pharmacother 2010;44:800-8. Full $\underline{\text { Text }}$

88. DiMatteo MR, Giordani PJ, Lepper HS, Croghan TW. Patient adherence and medical treatment outcomes: a meta-analysis. Med Care 2002;40:794-811. Full $\underline{\text { Text }}$

89. DiMatteo MR. Variations in patients' adherence to medical recommendations: a quantitative review of 50 years of research. Med Care 2004;42:200-9. Full Text

90. Yach D, Stuckler D, Brownell KD. Epidemiologic and economic consequences of the global epidemics of obesity and diabetes. Nature Med 2006;12:62-6. Full Text

91. Davis WA, Bruce DG, Davis TME. Economic impact of moderate weight loss in patients with type 2 diabetes: The Fremantle Diabetes Study. Diabet Med 2011;28:1131-5. Full Text

92. Ahn AC, Tewari M, Poon CS, Phillips RS. The clinical applications of a systems approach. PLoS Med 2006;3:e209. Full Text

93. Ahn AC, Tewari M, Poon CS, Phillips RS. The limits of reductionism in medicine. Could systems biology offer an alternative? PLoS Med 2006;3:e208. Full $\underline{\text { Text }}$
94. Mezuk B, Rafferty JA, Kershaw KN, et al. Reconsidering the role of social disadvantage in physical and mental health: stressful life events, health behaviors, race and depression. Am J Epidemiol 2010;172:1238-49. Full Text

95. Smilkstein G, Ashworth C, Montano D. Validity and reliability of the Family APGAR as a test of family function. J Fam Pract 1982;15:303-11.

96. Cohen S, Kamarck T, Mermelstein R. A global measure of perceived stress. J Health Soc Behav 1983;24:385-96. Full Text

97. Elo AL, Leppanen A, Jahkola A. Validity of a singleitem measure of stress symptoms. Scand J Work Environ Health 2003;29:444-51. Full Text

98. de Boer AG, van Lanschot JJ, Stalmeier PF, et al. Is a single-item visual analogue scale as valid, reliable and responsive as multi-item scales in measuring quality of life? Qual Life Res 2004;13:311-20. Full Text

99. Goldfarb-Rumyantzev AS, Rout P, Sandhu GS, Khattak M, Tang H, Barenbaum A. Association between social adaptability index and survival of patients with chronic kidney disease. Nephrol Dial Transplant 2010;25:3672-81. Full Text 